\title{
EFFECT OF METHIONINE SULFOXIMINE ON METHYLATION OF GUANINE RESIDUES IN ASTROGLIAL TRANSFER RIBONUCLEIC ACIDS
}

\author{
Otto Z. Sellinger and Orchid Der ${ }^{1}$ \\ Laboratory of Neurochemistry \\ Mental Health Research Institute \\ University of Michigan Medical Center \\ Ann Arbor, Michigan 48109
}

Accepted September 23, 1980

\begin{abstract}
Culture-grown astrocytes derived from 3-day-old rat brain were incubated in the presence of $\left[{ }^{3} \mathrm{H}\right]$ guanosine and of the convulsant agent $\mathrm{L}$-methionine- $d l$-sulfoximine (MSO). The resulting $\left[{ }^{3} \mathrm{H}\right] \mathrm{tRNA}$ was purified from control and MSO-exposed cells at several time points during the incubation and was hydrolyzed to $\left[{ }^{3} \mathrm{H}\right]$ guanine and four $\left[{ }^{3} \mathrm{H}\right]$ methyl guanines which were separated by high pressure liquid chromatography. Three of the four $\left[{ }^{3} \mathrm{H}\right]$ methyl guanines were more highly labeled in the $\left[{ }^{3} \mathrm{H}\right] \mathrm{tRNA}$ of the MSO-exposed cells, relative to that of the control cells throughout the entire incubation period. The findings extend to cultured astrocytes, the stimulatory effect of MSO on the methylation of neural tRNA guanines, previously observed both in vitro using $\left[{ }^{14} \mathrm{C}\right] S$-adenosyl-L-methionine

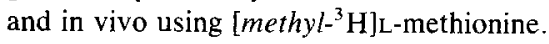

\section{INTRODUCTION}

It is generally recognized that in non-neural cells post-transcriptional modifications of tRNA structure contribute in a large, but as yet incompletely understood, measure to make protein synthesis cell-specific. Since the processing of cerebral tRNA remains active throughout the first month of postnatal development (1-5) and since, as we have recently shown,

\footnotetext{
' Present address: Department of Pharmacology, The University of Wisconsin Center for Health Sciences, Madison, Wisconsin 53706.
} 
cerebral tRNA-modifying reactions are affected in vivo and their pattern of specificity altered by the convulsant agent $\mathrm{L}$-methionine- $d l$-sulfoximine (MSO) (6), it appeared of interest to examine effects of MSO on the biosynthesis of neural tRNA. We chose to study this (7) in culture-grown astroglial cells (astrocytes) derived from the 3-day-old rat cerebral cortex (8), primarily because there is substantial cytological evidence that MSO affects the glial compartment of brain more significantly than the neuronal one $(9,10)$, and also because glutamine synthetase, an enzyme activity strongly inhibited by MSO in brain tissue (11), is now known to be an exclusively glial protein (12).

\section{EXPERIMENTAL PROCEDURE}

Astrocyte Culture. The culture procedure was as described previously (8), the cells being grown in plates $75 \mathrm{~cm}^{2}$ containing $10 \mathrm{ml}$ of growth medium (7). Briefly, forebrains of 3 to 4-day-old rats were dissected under sterile conditions, minced, and trypsinized in $0.25 \%$ trypsin in Earle's balanced salt solution (BSS). The suspension was centrifuged, and the pellet was washed once in BSS, and diluted to yield 10 plates per forebrain. Cells were grown in a medium composed of $10 \%$ fetal bovine serum in minimum essential medium, with either Earle's or Hanks' BSS. The medium was supplemented with 100 units penicillin, $100 \mu \mathrm{g}$ streptomycin, and 100 units polymyxin per ml medium. Cells were grown in a National incubator, in an atmosphere of $95 \%$ air and $5 \% \mathrm{CO}_{2}$. The medium was changed on days 4,8 , and 11 , and the cells harvested by days 17-19.

Exposure of Astrocytes to $\left[{ }^{3} \mathrm{H}\right]$ Guanosine and MSO. At specified intervals (see Results) preceding the harvesting of the cells, the growth medium received $62.5 \mu \mathrm{Ci}$ of $\left[{ }^{3} \mathrm{H}\right]$ guanosine $(14.5 \mathrm{Ci} / \mathrm{mM})$. Half the plates also received $10 \mathrm{mg}$ of $\mathrm{MSO} /$ plate $2 \mathrm{hr}$ before they were harvested and their RNA extracted. Under these conditions, the cells appeared unchanged and no evidence of toxicity was noted on inspection. A systematic study of the effect of MSO on cell viability was not intended in this study.

IRNA Extraction. The extraction procedure has been described in detail previously (7). Briefly, the medium was decanted and the cells rinsed with phosphate-buffered saline containing, in g/liter: $\mathrm{CaCl}_{2}$ and $\mathrm{MgCl}_{2}, 0.1 ; \mathrm{KCl}$ and $\mathrm{KH}_{2} \mathrm{PO}_{4}, 0.2, \mathrm{NaCl}, 8$; and $\mathrm{Na}_{2} \mathrm{HPO}_{4}$, 215. Equal volumes of TNE buffer $(0.01 \mathrm{M}$ Tris $\mathrm{HCl}, \mathrm{pH} 7.8,0.1 \mathrm{M} \mathrm{NaCl}, 0.01 \mathrm{M} \mathrm{Na}$ EDTA) in diethylpyrocarbonate-treated water containing $10 \mathrm{mM} \mathrm{MgCl}{ }_{2}$ and $\beta$-mercaptoethanol, $\mathrm{pH} 8.2$, were mixed with TNE-saturated phenol and used to transfer the cells into test tubes to which were added $5 \mathrm{ml}$ of $\mathrm{CHCl}_{3}$ followed by vigorous agitation and incubation, with shaking, at $60^{\circ} \mathrm{C}$ for $40 \mathrm{~min}$. Three volumes of $95 \%$ ethanol were added to the aqueous phase resulting from a $9000 \mathrm{~g}, 15$-min centrifugation of the above suspension, and the RNA was allowed to collect overnight at $-20^{\circ} \mathrm{C}$.

Hydrolysis of tRNA and Separation of its Guanine and Methyl Guanines. A tRNA fraction was obtained following suspension of the centrifuged RNA pellet in $0.01 \mathrm{M}$ Tris $\mathrm{HCl}$, containing $0.01 \mathrm{M} \mathrm{MgCl}_{2}, 0.001 \mathrm{M}$ EDTA, and $0.05 \mathrm{M} \mathrm{NaCl}, \mathrm{pH} 7.5$ (buffer A), and chromatography on DEAE-cellulose (13). The tRNA fraction was eluted with $0.7 \mathrm{M} \mathrm{NaCl}$. Following dialysis to remove $\mathrm{NaCl}$ and lyophilization, the tRNA was hydrolyzed according to Klagsbrun (14). Separation of the guanine from 1-methyl-, 7-methyl-, $N^{2}$-methyl, and $N_{2}^{2}$-dimethyl guanine was accomplished using $\operatorname{HPLC}(7,15)$. 
tRNA Aminoacylation. The rat liver or brain aminoacyl-tRNA synthetases were prepared as described (7). Aminoacylation of astrocyte tRNA was carried out in a reaction volume of $1 \mathrm{ml}$ containing, in order of addition: $1 \mu \mathrm{Ci}\left[{ }^{3} \mathrm{H}\right]$ lysine or phenylalanine; $0.4 \mathrm{M}$ Tris $\mathrm{HCl}$, $\mathrm{pH} 7.5 ; 20 \mathrm{mM}$ (for lysine) or $50 \mathrm{mM}$ (for phenylalanine) $\mathrm{KCl} ; 10 \mathrm{mM}$ (for lysine) or $20 \mathrm{mM}$ (for phenylalanine) $\mathrm{MgCl}_{2} ; 1 \mathrm{mM}$ (for lysine) or $4 \mathrm{mM}$ (for phenylalanine) ATP; $0.6 \mathrm{mM}$ CTP; $2 \mathrm{mM}$ B-mercaptoethanol; 0.3-0.5 $\mathrm{A}_{260}$ units of tRNA; and 0.4-0.8 $\mathrm{mg}$ of aminoacyl-tRNA synthetase protein. Incubation was for $10 \mathrm{~min}$ at $37^{\circ} \mathrm{C}$. The procedure of Yang and Novelli (16) was used to isolate and quantitate the $\left[{ }^{3} \mathrm{H}\right]$ aminoacyl-tRNA.

\section{RESULTS}

RNA Yield and tRNA Aminoacylation. Growing astrocytes for 17 days yielded 1.4-1.5 $\mathrm{A}_{260}$ units per culture dish. The aminoacylating capacity of the tRNA extracted from ten control and ten MSO-exposed dishes is compared in Table I. Lysine acceptance was between 60- and 100-fold higher than phenylalanine acceptance when the hepatic tRNA-aminoacyl synthetase was used; acceptance values were lower when the tRNA-aminoacyl synthetase preparation was derived from brain tissue.

Incorporation of $\left[{ }^{3} H\right]$ Guanosine into Astroglial $R N A$ and $t R N A$. The labeling of total RNA as a function of the exposure time (1-8 hr) to $\left[{ }^{3} \mathrm{H}\right]$ guanosine and to MSO ( $2 \mathrm{hr}$ ) is shown in Figure 1, while Figure 2 depicts the specific radioactivity (sra) of the $\left[{ }^{3} \mathrm{H}\right] \mathrm{tRNA}$ fraction. Figure 1 indicates a negligible amount of total RNA labeling during the initial 3-3.5 hr, while Figure 2 illustrates a gradual increase in the sra of $\left[{ }^{3} \mathrm{H}\right]$ tRNA between 2.5 and $3 \mathrm{hr}$, followed by a steep labeling spurt in both control and MSO-exposed cells between 3 and $4 \mathrm{hr}$. The figures also show a uniformly higher incorporation into total RNA in control cells and higher than control $\left[{ }^{3} \mathrm{H}\right]$ tRNA sra values in the MSO-exposed cells during the second half of the $\left[{ }^{3} \mathrm{H}\right]$ guanosine incorporation process.

Effect of MSO on Incorporation of $\left[{ }^{3} \mathrm{H}\right]$ Guanosine into Guanine and Methyl Guanine Residues of Glial tRNA. Following hydrolysis of $\left[{ }^{3} \mathrm{H}\right]$ tRNA at each time period indicated in Figure 2, its $\left[{ }^{3} \mathrm{H}\right]$ guanine residues were separated from its $\left[{ }^{3} \mathrm{H}\right]$ methyl guanine residues by HPLC (15). Figure 3 illustrates the distribution of the radioactivity at the two early time points among four individual $\left[{ }^{3} \mathrm{H}\right]$ methyl guanines and in their sum $\left(\sum \mathrm{mG}\right)$. Initially, $\left[{ }^{3} \mathrm{H}\right]$ methyl guanines represented a much higher proportion of the $\left[{ }^{3} \mathrm{H}\right]$ tRNA formed in the MSO-treated than in the control cells, relative to $\left[{ }^{3} \mathrm{H}\right]$ guanine. This "hypermethylating" effect of MSO was particularly evident at the level of the two $N$-methylated guanines, which accounted for $10 \%$ of the total radioactivity in the MSO-treated, as against $1.6 \%$ in the control, cells at $1.5-1.75$ hours. Conversely, at the same time, $\left[{ }^{3} \mathrm{H}\right] 1$-methyl guanine represented 2.9 and $0.6 \%$ of the 
$\left[{ }^{3} \mathrm{H}\right] \mathrm{tRNA}$ formed in the control and the MSO-exposed cells, respectively. These findings thus reveal not only marked differences in the early labeling pattern of the individual $\left[{ }^{3} \mathrm{H}\right] \mathrm{tRNA}$ methyl guanines between control and MSO-treated astrocytes, but they also confirm the previously described ability of this agent to alter the specificity of neural tRNA methyltransferases $(6,17)$.

By $8 \mathrm{hr}$ of incubation all four tRNA guanine residues were affected by MSO (Table II). Particularly striking in this respect was the more than twofold increase over control values in 1-methyl guanine and $N_{2}^{2}$-dimethyl guanine radiactivity.

\section{DISCUSSION}

The exposure of the astrocytes to $\left[{ }^{3} \mathrm{H}\right]$ guanosine and, in the case of the experimental group of cells, to $1 \mathrm{mg} / \mathrm{ml} \mathrm{MSO}$ for $2 \mathrm{hr}$ as well, resulted in the labeling profile for total cellular RNA shown in Figure 1. Several reasons may account for the observed temporal delay $(3-3.5 \mathrm{hr})$ in RNA labeling, most of which can only be speculated upon, since very little is known about glial transport, metabolism, and the tRNA precursor properties of guanosine. It is known, however, that brain has an active system of enzymes involved in nucleoside interconversions and phosphorylation (18) and that it is rich in a guanosine-inosine-specific phosphorylase (19, 20) which is distinct from the nucleoside phosphorylase utilizing adenosine. It is not known whether in neural cells, as is likely to be the case in Novikoff hepatoma cells (21), this enzyme exists in more than one

TABLE I

Aminoacylation of Astroglial tRNA by Liver and Brain tRNA AMINOACYLTRANSFERASES

\begin{tabular}{|c|c|c|c|c|}
\hline \multirow[b]{2}{*}{ Amino acid } & \multicolumn{2}{|c|}{ Liver enzyme $^{a}$} & \multicolumn{2}{|c|}{ Brain enzyme ${ }^{a}$} \\
\hline & Control tRNA ${ }^{b}$ & MSO tRNA ${ }^{b}$ & Control tRNA ${ }^{b}$ & MSO tRNA ${ }^{b}$ \\
\hline Lysine & 12.9 & 16.8 & 8.4 & 11.5 \\
\hline Phenylalanine & 0.21 & 0.18 & 0.06 & 0.05 \\
\hline
\end{tabular}

${ }^{a}$ Values (averages of two separate experiments) are in $\mathrm{pmol} / \mathrm{A}_{\mathbf{2 6 0}} / \mathrm{mg}$ protein. Liver and brain enzyme refer to $t R N A$ aminoacyltransferase preparations partially purified (7) from adult rat liver and brain.

${ }^{b}$ Control and MSO tRNA refer to tRNA isolated, respectively, from normal astrocytes and from astrocytes exposed for $2 \mathrm{hr}$ to $1 \mathrm{mg} /$ liter of MSO. 


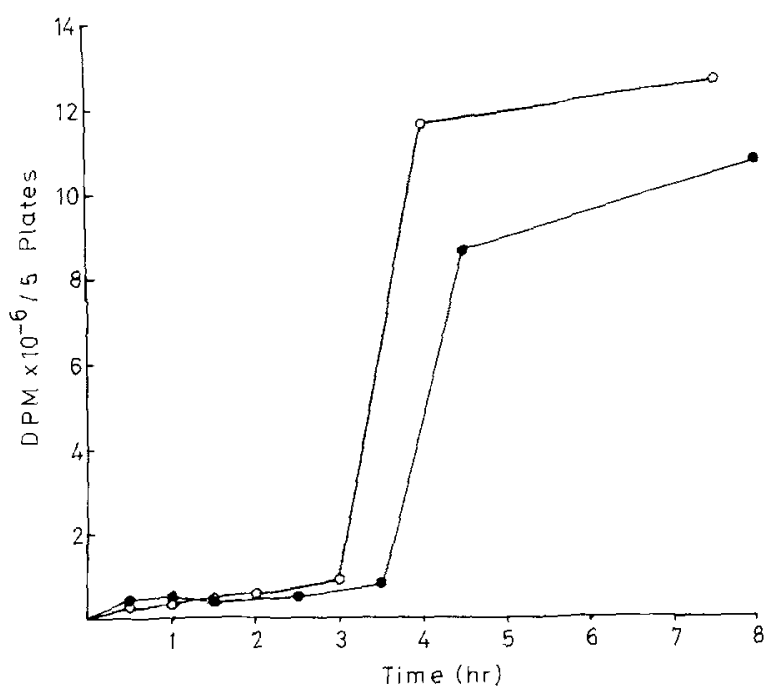

FiG. 1. The incorporation of $\left[{ }^{3} \mathrm{H}\right]$ guanosine into astrocyte ribonucleic acids. Astrocytes grown for 17 days were incubated in the presence of $\left[{ }^{3} \mathrm{H}\right]$ guanosine and $\mathrm{MSO}$, as described in Experimental Procedure. At the times indicated and for the most part with half-hour displacements between the control and the MSO-exposed cells (for reasons of ease of manipulation), the cells of 10 plates were subjected to RNA extraction and the determination of its radioactivity. $O=$ control cells; $\bullet=$ cells exposed to MSO for $2 \mathrm{hr}$.

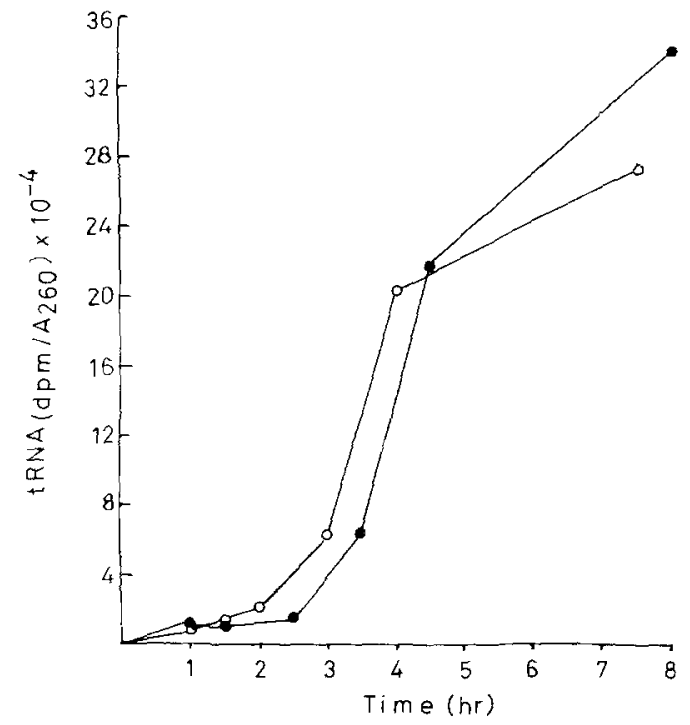

FIG. 2. The specific radioactivity of $\left[{ }^{3} \mathrm{H}\right] \mathrm{tRNA}$. The $\left[{ }^{3} \mathrm{H}\right] \mathrm{tRNA}$ fraction was obtained from the $\left[{ }^{3} \mathrm{H}\right] \mathrm{RNA}$ depicted in Figure 1 and its radioactivity and $\mathrm{A}_{260}$ content were determined, as indicated. $\mathrm{O}=$ control cells; $\bullet=$ cells exposed to $\mathrm{MSO}$ for $2 \mathrm{hr}$. 

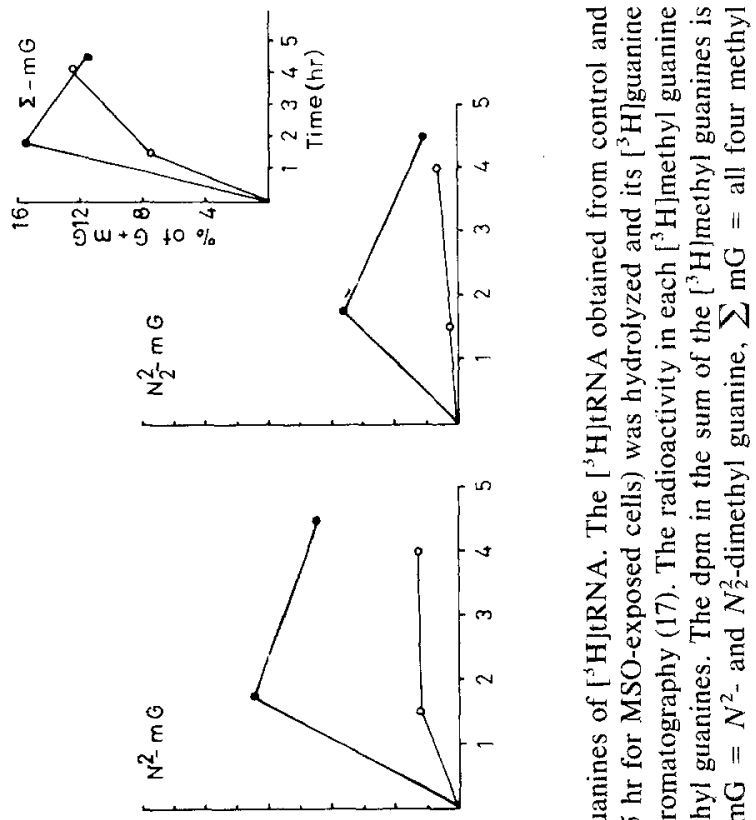

$-\frac{0}{2}=$

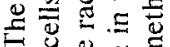

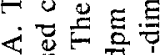
Z $\simeq$ 国走 I

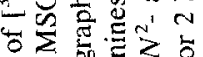

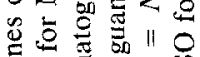

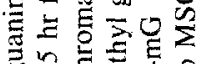

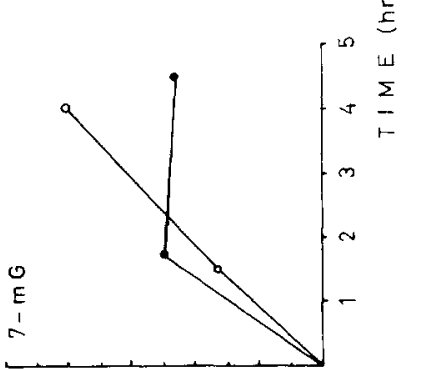

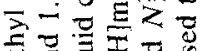

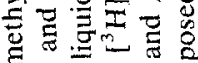
Iㅁํㄴ

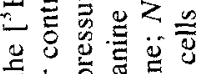

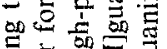

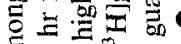

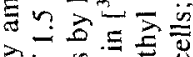
녕

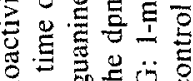

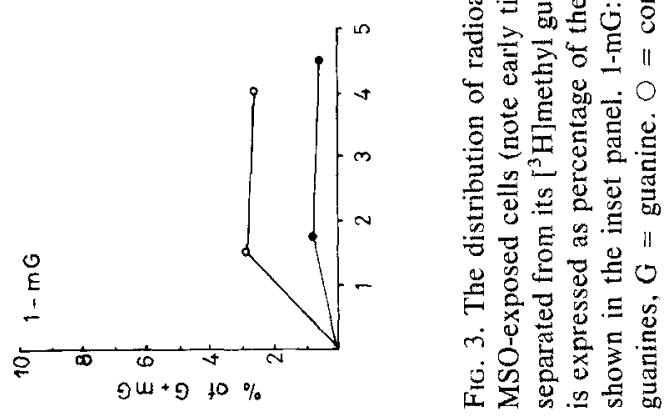


ASTROGLIAL TRNA




intracellular location, i.e., in the soluble cell sap and in the plasma membrane.

The formation of glial RNA from $\left[{ }^{3} \mathrm{H}\right]$ guanosine was recently reported by Yanagihara (22), who found it to be higher than in neurons and who also noted a 6.5 -fold higher uptake of $\left[{ }^{3} \mathrm{H}\right]$ guanosine by bulk-isolated glial cells, relative to neuronal perikarya. The labeling of astrocytic tRNA (Figure 2), recently examined in the 3-day-old rat brain in vivo (7), began sluggishly, but from 3 to $3.5 \mathrm{hr}$ onward its specific radioactivity (sra) increased by more than threefold in $1 \mathrm{hr}$. The effect of MSO appeared to be biphasic in nature, i.e., $\left[{ }^{3} \mathrm{H}\right] \mathrm{tRNA}$ formation was lower than in control cells up to $3.5 \mathrm{hr}$, becoming higher in the second half of the labeling period and reaching 20\% higher than control sra values by $8 \mathrm{hr}$. It is not possible at this time to fully assess the reasons for the biphasic effect of MSO since it is not possible to correlate its action on the $\left[{ }^{3} \mathrm{H}\right]$ guanosine incorporating process to its inracellular concentration. It is likely, however, that MSO entered the astrocytes with no difficulty since, using $\left[{ }^{3} \mathrm{H}\right] \mathrm{MSO}$, we showed its entry into the brain to be relatively unencumbered under a number of different experimental conditions (23, 24). On the cellular level, a glial locale for its early action, i.e., during the $3 \mathrm{hr}$ following its administration to rodents, has been suggested. We showed an apparent concentration of $\left[{ }^{3} \mathrm{H}\right] \mathrm{MSO}$ in bulk-isolated astrocytes during the first hour following its intrathecal administration to 18-day-old rats (25), while, more recently, Phelps (9) reported an accumulation of glycogen in astrocytes following MSO, a finding further explored by Berel et al. (26) and Hevor and Gayet (27).

The early effects of MSO on the methylation of the four individual tRNA guanines were of three different sorts: higher than control for $N^{2}$ methyl and $N_{2}^{2}$-dimethyl guanine, lower than control for 1-methyl guanine and both higher and lower than control for 7-methyl guanine (Figure 3). By $8 \mathrm{hr}$, however (Table II), the sra of the $\left[{ }^{3} \mathrm{H}\right] \mathrm{tRNA}$ formed in the MSOexposed cells had overtaken the control value by $36 \%$, and the radioactivity of all $\left[{ }^{3} \mathrm{H}\right]$ methyl guanines was higher by an average of $102 \%$. These results complement our previous findings $(6,17)$ of an effect of MSO on rat brain guanine tRNA methyltransferases. It is of interest that Brunke et al. (28) recently reported that the administration of the carcinogen 9,10dimethyl-1,2-benzanthracene specifically stimulates the $N^{2}$-guanine tRNA methyltransferase of rat mammary gland tumors, while Glazer and Hartman (30) reported this enzyme to be the primary target of 5-azacytidine and dihydro-5-azacytidine action in murine leukemia L1210 cells. Whether glial $N^{2}$-guanine tRNA methyltransferase is a primary target of MSO action awaits elucidation. 


\section{ACKNOWLEDGMENTS}

The research was supported by grant NINCDS-06294 from the United States Public Health Service. We gratefully acknowledge the excellent technical assistance of Denise Bond and Wayne G. Ohlsson.

\section{REFERENCES}

1. Sellinger, O. Z., Dainat, J., and Salas, C. E. 1977. The relationship of tRNA methylation to brain protein synthesis during cortical and cerebellar development. Pages 55-70, in Roberts S., Lajtha, A., and GisPen, W. H. (eds.), Mechanisms, regulation and special functions of protein synthesis in the brain, Elsevier/North Holland Press, Amsterdam.

2. Cummins, C. J., Salas, C. E., and Sellinger, O. Z. 1975. The homologous methylation of tRNA in rat brain. Brain Res. 96:407-412.

3. Elahi, E., and Sellinger, O. Z. 1979. The postnatal methylation of transfer ribonucleic acid in brain: Evidence for the methylation of precursor transfer ribonucleic acid. Biochem. J. 177:381-384.

4. Johnson, T. C., Mathews, R. A., and Chou, L. 1974. tRNA methyltransferase activity in neonatal and mature mammalian neural tissue. J. Neurochem. 23:489-496.

5. Dainat, J., and Sellinger, O. Z. 1980. Cerebellar tRNA methyltransferases: A developmental study. Brain Res. 183:135-143.

6. Dainat, J., Salas, C. E., and Sellinger, O. Z. 1978. Alteration of the specificity of brain tRNA methyltransferases and of the pattern of brain tRNA methylation in vivo by methionine sulfoximine. Biochem. Pharmacol. 27:2655-2658.

7. Sellinger, O. Z., and Der, O. 1980. The biosynthesis of transfer ribonucleic acid in the developing rat brain and in cultured glial cells. J. Neurochem. 35:1436-1445.

8. Cummins, C. J., and Glover, R. A. 1978. Propagation and histological characterization of a homotypic population of astrocytes derived from neonatal rat brain. J. Anat. 125:117-125.

9. Phelps, G. C. 1975. An ultrastructural study of methionine sulphoximine-induced glycogen accumulation in astrocytes of the mouse cerebral cortex. J. Neurocytol. 4:479-490.

10. Rizzuto, N., and Gonatas, N. K. 1974. Ultrastructural study of the effect of methionine sulfoximine on developing and adult rat cerebral cortex. J. Neuropathol. Exp. Neurol. $33: 237-250$.

11. Lamar, C., JR., and Sellinger, O. Z. 1965. The inhibition in vivo of cerebral glutamine synthetase and glutamine transferase by the convulsant methionine sulfoximine. Biochem. Pharmacol. 14:489-506.

12. Norenberg, M. D., and Martinez-Hernandez, A. 1979. Fine structural localization of glutamine synthetase in astrocytes of rat brain. Brain Res. 161:303-310.

13. JANK, P., and Gross, H. J. 1974. Methyl-deficient mammalian transfer RNA. II. Homologous methylation in vitro of liver tRNA from normal and ethionine-fed rats: Ethionine effect on 5-methyl cytidine synthesis in vivo. Nucleic Acids Res. 1:1259-1267.

14. Klagsbrun, M. 1972. The contrast between the methylation of transfer ribonucleic acid in vivo and in vitro by normal and SV40 transformed 3 T3 cells. J. Biol. Chem. 247:7443-7451. 
15. Salas, C. E., and Sellinger, O. Z. 1977. Rapid, quantitative separation by highperformance liquid chromatography of methylated bases in transfer RNA. J. Chromatogr. 133:231-236.

16. YANG, W. K., and NovelLI, G. D. 1971. Analysis of isoaccepting tRNAs in mammalian tissues and cells. Pages 44-45, in Moldave, K., and Grossman, L. (eds.), Methods in Enzymology, Vol. XX, Part C, Academic Press, New York.

17. Salas, C. E., Ohlsson, W. G., and Sellinger, O. Z. 1977. The stimulation of cerebral $N^{2}$-methyl- and $N_{2}^{2}$-dimethyl-guanine-specific tRNA methyltransferases by methionine sulfoximine. Biochem. Biophys. Res. Commun. 76:1107-1115.

18. Macdonnell, P., Huff, K., Grouse, L., and Guroff, G. 1980. Brain nucleic acids. Pages 211-240, in Kumar, S. (ed.), Biochemistry of Brain, Pergamon Press, Elmsford, New York.

19. Kluge, H., Hartmann, W., Zahlten, W., and Ring, U. 1971. Aktivitaetsbestimmung der Purinnukleosid-Phosphorylase aus Rattenhirn durch Produktauftrennung an Kationenaustauschern. J. Chromatogr. 56:365-367.

20. Snyder, F. F., Cruikshank, M. K., and Seegmiller, J. E. 1978. A comparison of purine metabolism and nucleotide pools in normal and hypoxanthine-guanine phosphoribosyltransferase-deficient neuroblastoma cells. Biochim. Biophys. Acta 543:556-569.

21. MAy, R. A., and HoffeE, P. 1978. Guanosine metabolism in Novikoff hepatoma cells: Isolation and characterization of guanosine resistant variants. Arch. Biochem. Biophys. 190:712-719.

22. Yanagihara, T. 1979. Protein and RNA synthesis and precursor uptake with isolated nerve and glial cells. J. Neurochem. 32:169-177.

23. Ghittoni, N. E., Ohlsson, W. G., and Sellinger, O. Z. 1970. The effect of methionine on the regional and intracellular disposition of methionine sulphoximine in rat brain. $\mathbf{J}$. Neurochem. 17:1057-1068.

24. Schatz, R. A., Harris, R., and Sellinger, O. Z. 1976. The effect of methionine on the uptake, distribution and binding of the convulsant methionine sulphoximine in the rat. Neurochem. Res. 1:53-63.

25. Sellinger, O. Z., Azcurra, J. M., Johnson, D. E., Ohlsson, W. G., and Lodin, Z. 1971. Independence of protein synthesis and drug uptake in nerve cell bodies and glial cells isolated by a new technique. Nature (London), New Biol. 230:253-256.

26. Berel, A., Lehr., P. R., and Gayet. J. 1977. Inhibition by metyrapone of convulsions and storage of brain glycogen in mice induced by methionine sulfoximine (MSO). Brain Res. 128:193-196.

27. Hevor, T. K., and GAYET, J. 1979. Cyclic nucleotides in the brain of mice and rats submitted to the convulsant, methionine sulfoximine. Biochem. Pharmacol. 28:3507-3512.

28. Brunke, K. J., Strickler, G., and Leboy, P. S. 1980. Elevated methylation capacity of selected transfer RNA methyltransferases from 9,10-dimethyl-1,2-benzanthraceneinduced rat mammary tumors. Cancer Res. 40:417-423.

29. Glazer, R. I., and Hartman, K. E. 1980. The comparative effects of 5-azacytidine and dihydro-5-azacytidine on $4 \mathrm{~S}$ and 5S nuclear RNA. Mol. Pharmacol. 17:250-255. 